\title{
Analisis Efektivitas Pendapatan Asli Daerah dan Dana Perimbangan di Kabupaten Kerinci Tahun 2011 - 2016
}

\author{
${ }^{1}$ Murniati \\ ${ }^{1}$ STIE Sakti Alam Kerinci \\ murniatimsi@gmail.com
}

\begin{abstract}
This research entitled the effectiveness of Revenue Equalization Fund and regional Original in Kerinci 2011-2016 Year, with the aim to find out how large the original revenue growth areas and Fund Balances in the Regency of Kerinci 2011-2016 Year and To find out how large a rate Efekstivitas the original Revenue Equalization Fund and Areas in Kerinci 2011-2016 Year. This research dalaksanakan in the District of Kerinci using Secondary data, with data collection techniques Research Library with Descriptive method quantitative and qualitative descriptive. As for the analysis tools used i.e. the ratio of the growth and the ratio of effectiveness. Based on the results of the study showed that the original receipt of an income Growth Areas in the Regency of Kerinci from year 2011 - 2016 is always increasing. While the percentage of growth experiencing fluctuations. The average nominal Target for 6 years 2011-2016 years of Rp. 49,597,954,211, where the average target percentase 2011-2016 year of 17.79\%. Growth targets and the realization of Equalization Funds in the Regency of Kerinci, explained that in nominal target of receiving funds from the balance of the year 2011-2016 in total amounting to $R p$. 3.767.521., 800.135,20 average per year or $R p$. $627,920,300,022.53$. So also with the percentage growth target receiving funds Balances experienced fluctuation that is $20.53 \%$ average. Whereas the effectiveness of the original Income Areas in the Regency of Kerinci Years 2011 2016, an average realization of greater than the target which entered criteria very effectively with the value of the average of 105.79\%. The effectiveness of the Equalization Funds in the District of Kerinci 2011-2016 Years, on average exceeds its realization of targets set. It means that by the criterion of effectiveness including the categories very effectively with an average effectiveness of 100.39 percentasi\%.
\end{abstract}

Keywords: effectiveness, Revenue Equalization Fund and regional Original

\section{PENDAHULUAN}

Undang-Undang No. 32 Tahun 2004 tentang Pemerintah Daerah serta UU No. 33 Tahun 2004 tentang Perimbangan Keuangan antara Pemerintah Pusat dan Daerah sebagai dasar penyelenggaraan otonomi daerah. Misi utama kedua undang-undang tersebut adalah desentralisasi. Desentralisasi tidak hanya berarti pelimpahan wewenang dari pemerintah pusat ke pemerintah yang lebih rendah, tetapi juga pelimpahan beberapa wewenang dari pemerintah ke pihak swasta dalam bentuk privatisasi (Mardiasmo, 2013). Penyelenggaraan desentralisasi terkait dengan pemerintah pusat dan pemerintah daerah, salah satunya adalah pembentukan daerah otonom dan penyerahan kekuasaan secara hukum dari pemerintah pusat ke pemerintah daerah untuk mengurus pemerintahannya masingmasing. Selaras dengan tujuan otonomi dan outcome, penyusunan APBD bertujuan untuk menyelaraskan kebijakan ekonomi makro dan sumber daya yang tersedia, mengalokasikan secara tepat sesuai kebijakan pemerintah dan 
mempersiapkan kondisi bagi pelaksanaan pengelolaan anggaran daerah yaitu menuntun kemandirian suatu daerah sehingga upaya harus dilakukan oleh pemerintah daerah untuk mengoptimalkan peningkatan Pendapatan Asli Daerah (PAD) dan sumber dana bagi daerah dalam rangka membiayai aktifitas operasional pemerintah daerah melalui pendapatan asli daerah yang berasal dari pajak dan retribusi daerah, dan sumber dana daerah melalui dana perimbangan yaitu dana alokasi umum, dana alokasi khusus, dan pendapatan transfer. Pendapatan Asli Daerah (PAD) merupakan pendapatan yang bersumber dari kegiatan ekonomi itu sendiri. Pendapatan Asli Daerah (PAD) merupakan salah satu pilar kemandirian suatu daerah. Undang-Undang Nomor 33 Tahun 2004 tentang perimbangan keuangan antara pemerintah pusat dan daerah, sumber PAD terdiri dari pajak daerah, retribusi daerah, hasil pengelolaan kekayaan daerah, dan lain-lain pendapatan daerah yang sah. Karena itu, kemampuan suatu daerah menggali PAD akan mempengaruhi perkembangan dan pembangunan daerah tersebut. Di samping itu semakin besar kontribusi PAD terhadap APBD, maka akan semakin kecil pula ketergantungan terhadap bantuan pemerintah pusat. Hal ini karena PAD dapat dipergunakan sesuai dengan kehendak dan inisiatif pemerintah daerah demi kelancaran penyelenggaraan urusan daerahnya (Bastian, 2012). Selain Pendapatan Asli Daerah (PAD), Dana Perimbangan juga merupakan salah satu sumber penerimaan daerah yang memiliki kontribusi besar terhadap struktur APBD. Undang-Undang No. 33 Tahun 2004 menyebutkan bahwa Dana Perimbangan adalah dana yang bersumber dari pendapatan APBD yang dialokasikan kepada daerah untuk mendanai kebutuhan daerah dalam rangka pelaksanaan desentralisasi tersebut. Pengelolaan dan pertanggungjawaban keuangan daerah telah ditetapkan pada Peraturan Pemerintah No 58 Tahun 2005 yang menegaskan bahwa pengelolaan keuangan daerah harus dilakukan secara tertib, taat pada peraturan perundangundangan yang berlaku, efisien, efektif, transparan, dan bertanggung jawab dengan memperhatikan atas keadilan dan kepatuhan (Bastian, 2012). Apabila pengelolaan daerah dilakukan dengan baik sesuai dengan peraturan yang telah ditetapkan, maka tentunya akan meningkatkan kinerja pemerintah daerah itu sendiri dan Efektivitas pun akan tercipta dengan baik.

\section{Tabel 1}

Realisasi Pendapatan Asli Daerah dan Dana Perimbangan Pemerintah Kabupaten Kerinci Tahun 2011-2016

\begin{tabular}{crr}
\hline Tahun & \multicolumn{1}{c}{ Realisasi } & \multicolumn{1}{c}{$\begin{array}{c}\text { Realisasi } \\
\text { Pendapatan Asli Daerah (Rp) }\end{array}$} \\
\hline 2011 & $34.924 .903 .019,66$ & $498.122 .606 .258,83$ \\
2012 & $32.020 .001 .879,23$ & $588.567 .045 .360,00$ \\
2013 & $36.470 .030 .655,34$ & $647.505 .131 .112,00$ \\
2014 & $59.626 .711 .527,91$ & $673.545 .200 .956,00$ \\
2015 & $70.463 .809 .684,80$ & $657.794 .536 .662,00$ \\
2016 & $81.320 .041 .327,77$ & $716.530 .728 .762,00$ \\
Jmlah & $\mathbf{3 1 4 . 8 2 5 . 4 9 8 . 0 9 4 , 7 1}$ & $\mathbf{3 . 7 8 2 . 0 6 5 . 2 4 9 . 1 1 0 , 8 3}$ \\
Rata-rata & $\mathbf{5 2 . 4 7 0 . 9 1 6 . 3 4 9 , 1 2}$ & $\mathbf{6 3 0 . 3 4 4 . 2 0 8 . 1 8 5 , 1 4}$ \\
\hline
\end{tabular}

Sumber: DPPKAD dan Laporan Kinerja Kabupaten Kerinci 
Pendapatan Asli Daerah (PAD) merupakan semua penerimaan yang diperoleh daerah dari sumber-sumber dalam wilayahnya sendiri yang dipungut berdasarkan peraturan daerah sesuai dengan peraturan perundang-undangan yang berlaku (Halim, 2004:96). Sektor pendapatan daerah memegang peranan yang sangat penting, karena melalui sektor ini dapat dilihat sejauh mana suatu daerah dapat membiayai kegiatan pemerintah dan pembangunan daerah. Pendapatan Asli Daerah (PAD) dan Dana Perimbangan memiliki peranan yang besar sebagai sumber pembiayaan pembangunan dan pada akhirnya mampu mendorong pertumbuhan ekonomi di daerah. Penurunan kegiatan ekonomi diberbagai daerah juga menyebabkan penurunan pendapatan daerah sehingga menghambat pelaksanaan kegiatan pemerintah, pembangunan, dan pelayanan masyarakat oleh pemerintah daerah secara otonom. Begitu juga sebaliknya peningkatan kegiatan ekonomi diberbagai daerah akan meningkatkan pendapatan daerah sehingga pelaksanaan kegiatan pemerintah, pembangunan, dan pelayanan masyarakat oleh pemerintah tidak terhambat.

Sesuai dengan latar belakang penelitian yang telah diuraikan sebelumnya, maka masalah yang akan dibahas dan diuraikan dalam penelitian ini adalah: 1) Berapa Besar Pertumbuhan Pendapatan Asli Daerah dan Dana Perimbangan di Kabupaten Kerinci Tahun 2011-2016?; 2) Berapa Besar Tingkat Efekstivitas Pendapatan Asli Daerah dan Dana Perimbangan di Kabupaten Kerinci Tahun 2011-2016?

Berdasarkan masalah pokok penelitian sebagaimana dijelaskan di atas, maka maksud dan tujuan dari penelitian ini adalah: 1) Untuk mengetahui Berapa Besar Pertumbuhan Pendapatan Asli Daerah dan Dana Perimbangan di Kabupaten Kerinci Tahun 2011-2016? 2) Untuk mengetahui Berapa Besar Tingkat Efekstivitas Pendapatan Asli Daerah dan Dana Perimbangan di Kabupaten Kerinci Tahun 2011-2016?

Manfaat dari penelitian ini adalah: 1) Hasil penelitian dapat digunakan untuk menambah referensi dibidang karya ilmiah yang dapat digunakan untuk mengembangkan ilmu pengetahuan; 2) Penelitian ini merupakan latihan dan pembelajaran dalam menerapkan teori yang diperoleh, sehingga menambahkan pengetahuan, pengalaman dan dokumentasi ilmiah; 3) Diharapkan dapat menjadi bahan pertimbangan bagi pemeritah Kabupaten Kerinci terhadap efektivitas pengelolaan PAD dan Dana Perimbangan, yang nantinya dapat digunakan sebagai bahan masukan dalam menetapkan kebijakan dibidang upaya peningkatan pendapatan asli daerah dimasa yang akan datang, khususnya yang bersumber dari lain-lain pendapatan asli daerah yang sah.

\section{Landasan Konseptual \\ Pengertian Pembangunan}

Menurut Fakih (2001:10) pembangunan adalah kata benda netral yang maksudnya adalah suatu kata yang digunakan untuk menjelaskan proses dan usaha yang meningkatkan kehidupan ekonomi, politik, budaya, infrastruktur masyarakat dan sebagainya. Sedangkan menurut Katz (dalam Yuwono, 2001:47) mengatakan pembangunan yang besar dari suatu keadaan tertentu ke keadaan yang dipandang lebih bernilai. Pada umumnya tujuan-tujuan pembangunan adalah pembinaan bangsa (national building) atau perkembangan sosial ekonomi. Maka untuk mencapai pembangunan yang telah dicanangkan selama ini bahwa peningkatan kesejahteraan manusia menjadi fokus sentral dari pembangunan dimana pelaksanaan pembangunan masyarakatlah yang menentukan tujuan, 
sumber-sumber pengawasan dan pengarahan proses-proses pelaksanaan pembangunan.

\section{Pengertian Pembangunan Ekonomi}

Menurut Adam Smith pembangunan ekonomi merupakan proses perpaduan antara pertumbuhan penduduk dan kemajuan teknologi (Suryana, 2002:55). Sedangkan menurut menurut Irawan (2002: 5) pembangunan ekonomi adalah usaha-usaha untuk meningkatkan taraf hidup suatu bangsa yang seringkali diukur dengan tinggi rendahnya pendapatan riil perkapita. Prof. Meier (dalam Adisasmita, 2005: 205) mendefinisikan pembangunan ekonomi sebagai proses kenaikan pendapatan riil perkapita dalam suatu jangka waktu yang panjang. Dari beberapa definisi diatas dapat disimpulkan bahwa pembangunan ekonomi merupakan suatu perubahan yang terjadi secara terus-menerus melalui serangkaian kombinasi proses demi mencapai sesuatu yang lebih baik yaitu adanya peningkatan pendapatan perkapita yang terus menerus berlangsung dalam jangka panjang.

\section{Pengertian Pertumbuhan Ekonomi}

Pertumbuhan ekonomi yang kita kenal selama ini mempunyai perspektif jangka panjang dan mempunyai beberapa definisi. Definisi tersebut, antara lain, adalah bahwa pertumbuhan ekonomi merupakan suatu proses kenaikan Produk Nasional Bruto Riil atau Pendapatan Nasional Riil. Oleh karena itu, pembangunan ekonomi selalu dibarengi dengan pertumbuhan ekonomi, dan sebaliknya, pertumbuhan ekonomi belum tentu disertai dengan pembangunan ekonomi.Secara umum, pertumbuhan ekonomi didefenisikan sebagai peningkatan kemampuan dari suatu perekonomian dalam memproduksi barang-barang dan jasa-jasa. Pertumbuhan ekonomi adalah salah satu indikator yang amat penting dalam melakukan analisis tentang pembangunan ekonomi yang terjadi pada suatu negara. Pertumbuhan ekonomi menunjukkan sejauh mana aktivitas perekomian akan menghasilkan tambahan pendapatan masyarakat pada suatu periode tertentu. Karena pada dasarnya aktivitas perekonomian adalah suatu proses penggunaan faktor-faktor produksi untuk menghasilkan output, maka proses ini pada gilirannya akan menghasilkan suatu aliran balas jasa terhadap faktor produksi yang dimiliki oleh masyarakat.

\section{Otonomi Daerah}

Undang-Undang No 32 Tahun 2004 menjelaskan definisi otonomi daerah, yaitu hak, wewenang, dan kewajiban daerah otonom untuk mengatur dan mengurus sendiri urusan pemerintahan dan kepentingan masyarakat setempat sesuai dengan peraturan perundang-undangan.Ada beberapa asas penting dalam undang-undang otonomi daerah yang perlu dipahami, antara lain:

1. Asas desentralisasi adalah penyerahan wewenang pemerintahan oleh pemerintah kepada daerah otonom dalam kerangka Negara Kesatuan Republik Indonesia.

2. Asas dekonsentrasi adalah pelimpahan wewenang pemerintahan oleh pemerintah kepada gubernur sebagai wakil pemerintah dan kepada instansi vertikal di wilayah tertentu.

3. Tugas pembantuan adalah penugasan dari pemerintah pusat kepada daerah dan/atau desa, dari pemerintah provinsi kepada kabupaten/kota dan/atau desa, serta dari pemerintah kabupaten/kota kepada desa untuk melaksanakan tugas tertentu. 
4. Perimbangan keuangan antara pemerintah pusat dan daerah adalah suatu sistem pembiayaan pemerintahan dalam kerangka negara kesatuan, yang mencakup pembagian keuangan antara pemerintah pusat dan daerah serta pemerataan antardaerah secara proporsional, demokratis, adil, dan transparan dengan memperhatikan potensi, kondisi, serta kebutuhan daerah, sejalan dengan kewajiban dan pembagian kewenangan serta tata cara penyelenggaraan kewenangan tersebut, termasuk pengelolaan dan pengawasan keuangannya.

\section{Keuangan Daerah}

Menurut Undang-undang No 23 Tahun 2014 tentang Pemerintah Daerah, bahwa keuangana daerah adalah semua hak dan kewajiban daerah yang dapat dinilai dengan uang dan segala sesuatu berupa uang dan barang yang dapat dijadikan milik daerah yang berhubungan dengan pelaksanaan hak dan kewajiban tersebut. Menurut Peraturan Pemerintah Nomor 58 tahun 2005 keuangan Daerah adalah smua hak dan kewajiban daerah dalam rangka penyelenggaraan pemerintah daerah yang dapat dinilai dengan uang termasuk didalamnya segala bentuk kekayaan yang berhubungan dengan hak dan kewajiban daerah tersebut. Adapun tujuan dari pengelolaan keuangan daerah dan organisasi pemerintah daerah adalah memeberrikan pelayanan yang prima bagi masyarakat di daerah yang merupakan client dari pemerintah daerah. Dalam hal ini semua unit pemerintah yang ada secara pokok difungsikan untuk melayani dengan sebaik-baiknya masyarakat yang bersangkutan.

\section{Anggaran Pendapatan dan Belanja Daerah}

Berdasarkan Undang-Undang Nomor 32 tahun 2004 anggaran pendapatan dan belanja daerah adalah suatu rencana keuangan tahunan pemerintah daerah yang ditetapkan dengan peraturan daerah. Anggaran merupakan artikulasi dari hasil perumusan dan strategi dan perencanaan strategik yang dibuat.Anggaran pendapatan dan belanja daerah berdasarkan Peraturan Menteri Dalam Negeri Nomor 13 tahun 2006, tentang pedoman pengelolaan keuangan daerah pasal 15 ayat 3 berbunyi APBD mempunyai fungsi otorisasi, perencanaan, pengawasan, alokasi distribusi dan stabilisasi. APBD menggambarkan segala bentuk kegiatan pemerintah daerah dalam mencari sumber-sumber penerimaan dan kemudian bagaimana dana-dana tersebut digunakan untuk mencapai tujuan pemerintah dalam kurun waktu satu tahun.

\section{Pendapatan Asli Daerah}

Undang-Undang Nomor 17 tahun 2003, pendapatan daerah adalah hak pemerintah daerah yang diakui sebagai penambah nilai kekayaan bersih. Penerimaan Pendapatan Asli Daerah (PAD) merupakan semua penerimaan yang diperoleh daerah dari sumber-sumber dalam wilayahnya sendiri yang dipungut berdasarkan peraturan daerah sesuai dengan peraturan perudang-undangan yang berlaku (Halim, 2013: 96). Berdasarkan pasal 79 Undang-Undang Nomor 22 Tahun 1999 tentang pemerintahan daerah, menyatakan Pendapatan Asli Daerah (PAD) adalah sesuatu yang diperoleh pemerintah daerah yang dapat diukur dengan uang karena kewenangan (otoritas) yang diberikan oleh masyarakat berupa hasil pajak daerah dan retribusi daerah, hasil perusahaan milik daerah dan pengelolaan kekayaan daerah serta lain-lain pendapatan daerah yang sah. Komponen PAD seperti retribusi daerah dan pajak secara langsung maupun tidak 
langsung akan membebani rakyat, sehingga komponen tersebut harus mendapatkan perhatian khusus.

Pendapatan daerah adalah semua penerimaan kas yang menjadi hak daerah dan diakui sebagai penambahan nilai kekayaan bersih dalam satu tahun anggaran dan tidak perlu dibayar kembali oleh pemerintah. Untuk mendapatkan pengertian yang lebih jelas mengenai pendapatan, telah dikemukakan beberapa definisi mengenai pendapatan daerah. Standar Akuntansi Pemerintah (SAP) No. 2 tentang Laporan Realisasi Anggaran (LRA) mendefinisikan bahwa pendapatan sebagai semua penerimaan rekening Kas Umum Negara dan Daerah yang menambah ekuitas dana lancar dalam periode tahun anggaran bersangkutan yang menjadi hak pemerintah dan tidak perlu dibayar kembali oleh pemerintah.

\section{Dana Perimbangan}

Dana perimbangan adalah sumber pendapatan daerah yang berasal dari APBN untuk mendukung pelaksanaan kewenangan pemerintah daerah dalam mencapai tujuan pemberian otonomi kepada daerah, yaitu terutama peningkatan pelayanan dan kesejahteraan masyarakat yang semakin baik (Djaenuri, 2012). Pada Undang-Undang No. 33 Tahun 2004 tentang perimbangan keuangan antara pemerintah pusat dan pemerintah, disebutkan bahwa dana perimbangan terdiri atas:

1. Dana Bagi Hasil

2. Dana Alokasi Umum

3. Dana Alokasi Khusus.

\section{Rasio Efektivitas}

Kemandirian dalam bidang keuangan di daerah, dapat diusahakan dengan meningkatkan Pendapatan Asli Daerah (PAD) dan mengurangi ketergantungan dari bantuan pusat. Upaya peningkatan PAD melalui pajak ataupun retribusi daerah akan berhasil bila pemerintah daerah menunjukkan itikad yang sungguhsungguh untuk meningkatkan pelayanan publiknya. Peningkatan pelayanan publik ini tercermin dengan meningkatnya proporsi belanja pembangunan. Menurut Mardiasmo (2004,9), pengukuran kinerja keuangan pemerintah daerah dilakukan untuk memenuhi 3 (tiga) tujuan yaitu sebagai berikut:

1. Memperbaiki kinerja pemerintah.

2. Membantu mengalokasikan sumber daya dan pembuatan keputusan.

3. Mewujudkan pertanggungjawaban publik dan memperbaiki komunikasi kelembagaan.

Salah satu formulasi yang dapat digunakan untuk megukur kinerja keuangan pemerintah daerah adalah dengan menghitung tingkat efektivitas pendapatan asli daerah. Berikut ini beberapa pendapat ahli tentang rasio efektivitas yang dapat digunakan oleh pemerintah daerah. Menurut Halim (2004:135), analisis efektivitas pendapatan asli daerah yaitu analisis yang menggambarkan kemampuan pemerintah daerah dalam merealisasikan pendapatan asli daerah yang direncanakan dibandingkan dengan target yang ditetapkan berdasarkan potensi riil daerah. Rumus yang digunakan untuk menghitung efektivitas adalah sebagai berikut:

$$
\text { Efektivitas PAD }=\frac{\text { Realisasi PAD }}{\text { Target PAD }} \times 100 \%
$$


Sejalan dengan pendapat Halim sebagaimana dijelaskan di atas, pendapat lain dikemukakan oleh Ulum (2008:49), bahwa efektivitas pada dasarnya berhubungan dengan pencapaian tujuan atau target kebijakan (hasil guna). Untuk menghitung efektivitas, yaitu dengan rumus sebagai berikut:

$$
\text { Efektivitas }=\frac{\text { Realisasi }}{\text { Target }} \times 100 \%
$$

Kriteria yang dapat digunakan untuk menginterprestasikan tingkat efektivitas pengelolaan keuangan daerah sebagaimana pendapat Halim (2002:129) sebagai berikut:

Kriteria Efektivitas

\begin{tabular}{cc}
\hline Persentase Realisasi $(\%)$ & Keterangan \\
\hline$<60,000$ & Tidak Efektif \\
$60,00-80,00$ & Kurang Efektif \\
$80,00-90,00$ & Cukup Efektif \\
$90,00-100,00$ & Efektif \\
$>100,00$ & Sangat Efektif \\
\hline
\end{tabular}

Sumber: Halim (2002:129)

\section{METODOLOGI PENELITIAN}

\section{Metode Pengumpulan Data}

Pengumpulan data dilakukan dengan cara (1) Penelitian Pustaka (Library Research) yaitu suatu teknik untuk mendapatkan data teoritis atau data sekunder dalam penelitian. Penelitian kepustakaan dilakukan dengan cara mempelajari buku-buku, literatur, dokumen-dokumen resmi, catatan dan transkrip, yang berkaitan dengan penelitian ini (2) Penelitian Lapangan (Field Research) yaitu penelitian langsung kelapangan dalam rangka mendapatkan data yang berhubungan dengan masalah yang diteliti

\section{Metode Analisis}

Metode analisis yang digunakan dalampenelitian ini adalah sebagai berikut:

1. Metode deskriptif kuantitatif

Metode deskriptif kuantitatif yaitu menjelaskan hasil penelitian yang berbentuk angka-angka, persentase yang telah dilakukan perhitungan yang berkaitan dengan permasalahan yang diteliti.

2. Metode deskriptif kualitatif

Merupakan metode analisis yang penjelasannya bukan berbentuk angka-angka, melainkan analisis secara kata-kata, kalimat, skema dan gambar. Analisis ini bertujuan untuk memberikan penjelasan, gambaran dan makna secara sistimatis mengenai fakta dan data yang diperoleh dari hasil penelitian.

\section{Alat Analisis Data}

Alat analisis yang digunakan dalam penelitian ini adalah

1. Rasio Pertumbuhan

2. Rasio Efektivitas

Rasio Pertumbuhan disini yaitu untuk mengetahui pertumbuhan Pendapatan Asli Daerah dengan Dana Perimbangan dimana sesuai dengan rumus pendapat dalam bukunya Sugiono (2004:37) sebagai berikut: 


$$
\mathrm{G}(\text { Growth })=\frac{\mathrm{P} 1-\mathrm{P} 0}{\mathrm{P} 0} \times 100 \%
$$

Keterangan :

$\mathrm{G}=$ Pertumbuhan

P1 = Nilai pada tahun ke 1

$\mathrm{P0} \quad=$ Nilai pada tahun sebelumnya

Rasio efektivitas adalah rasio kemampuan pemerintah daerah dalam merealisasikan pendapatan dari jasa giro yang dibandingkan dengan target yang ditetapkan dalam tahun anggaran yang bersangkutan. Rumus efektivitas yang digunakan mengacu pada pendapat Halim (2002:129) sebagai berikut:

$$
\text { Efektivitas }=\frac{\text { Realisasi }}{\text { Target }} \times 100 \%
$$

Kriteria Efektivitas:

\begin{tabular}{cc}
\hline Persentase Realisasi $(\%)$ & Keterangan \\
\hline$<60,00$ & Tidak Efektif \\
$60,00-79,99$ & Kurang Efektif \\
$80,00-89,99$ & Cukup Efektif \\
$90,00-100,00$ & Efektif \\
$>100,00$ & Sangat Efektif \\
\hline
\end{tabular}

Sumber: Halim (2002:129)

\section{HASIL DAN PEMBAHASAN}

\section{Pertumbuhan Target dan Realisasi Pendapatan Asli Daerah di Kabupaten Kerinci}

Berdasarkan data yang diperoleh dari Dinas Pendapatan, Pengelolaan Keuangan dan Aset Kabupaten Kerinci, maka pada tabel berikut ini dapat dilihat perkembangan target dan realisasi Pendapatan Asli Daerah di Kabupaten Kerinci selama 6 (enam) tahun terakhir yaitu dari tahun 2011 sampai dengan 2016.

\section{Tabel 2}

Persentase Pertumbuhan Realisasi Pendapatann Asli Daerah

Di Kabupaten Kerinci Tahun 2011 - 2016

\begin{tabular}{ccccc}
\hline \multirow{2}{*}{ Tahun } & Target $(\mathbf{R p})$ & Target dan Realisasi Pendapatan Asli Daerah & \\
& Pertumbuhan $(\boldsymbol{\%})$ & Realisasi (Rp) & Pertumbuhan $(\boldsymbol{\%})$ \\
\hline 2011 & $31.637 .183 .761,36$ & - & $34.924 .903 .019,66$ & - \\
2012 & $33.368 .190 .930,00$ & $5,47 \%$ & $32.020 .001 .879,23$ & $-8,32 \%$ \\
2013 & $40.783 .693 .656,00$ & $22,22 \%$ & $36.470 .030 .655,34$ & $13,90 \%$ \\
2014 & $55.083 .143 .310,00$ & $35,06 \%$ & $59.626 .711 .527,91$ & $63,50 \%$ \\
2015 & $66.598 .697 .406,32$ & $20,91 \%$ & $70.463 .809 .684,80$ & $18,17 \%$ \\
2016 & $70.116 .816 .200,00$ & $5,28 \%$ & $81.320 .041 .327,77$ & $15,41 \%$ \\
Jumlah & $297.587 .725 .263,68$ & $88,94 \%$ & $314.825 .498 .094,71$ & $102,66 \%$ \\
Rata-rata & $49.597 .954 .210,61$ & $17,79 \%$ & $52.470 .916 .349,12$ & $20,53 \%$ \\
\hline
\end{tabular}

Sumber : Data diolah 2018

Berdasarkan Tabel 2 dijelaskan bahwa secara nominal target penerimaan pendapatan asli daerah yang sah dari tahun 2011 - 2016 selalu mengalami peningkatan. Sedangkan persentase pertumbuhannya mengalami fluktuasi. RataRata Target nominal selama 6 tahun tahun 2011-2016 sebesar Rp. 49.597.954.211, dimana rata-rata target percentase tahun 2011-2016 sebesar 
17.79\%. Pada tahun 2012 target mengalami pertumbuhan sebesar 5,47\%, sedangkan realisasi sebaliknya turun sebesar -8,32\%, pada tahun 2013 target persentase pertumbuhan $22,22 \%$ sedangkan realisasinya tumbuh sebesar $13,90 \%$, Pada tahun 2014 target persentase mengalami pertumbuhan 35,06\% dan realisasi juga tumbuh sebesar Rp. 63,50\%. Sedangkan tahun 2015 target tumbuh sebesar realisasinya tumbuh sebesar $20,91 \%$, realisasi tumbuh sebesar $18,17 \%$, Pada tahun 2016 persentase target pertumbuhan meningkat hanya sebesar 5,28\% , realisasi tumbuh $15,41 \%$. Pertumbuhan atas target dan realisasi didukung dengan support pemerintah pusat dalam pendanaan pembangunan daerah yang diberikan sampai ke Desa dengan adanya Dana Desa, dan tahun 2015 dengan pengembangan BUMDES (Badan Usaha Milik Desa) sehingga program pembangunan semakin baik mulai dari perbaikan infrastrukur bangunan maupun jalan, fasilitas umum seperti pasar, tempat pariwisata, pertanian, dan lain sebagainya. Selain itu roda perputaran bisnispun meningkat dan belanja atau konsumsi masyarakat meningkat. Lihat gambar berikut

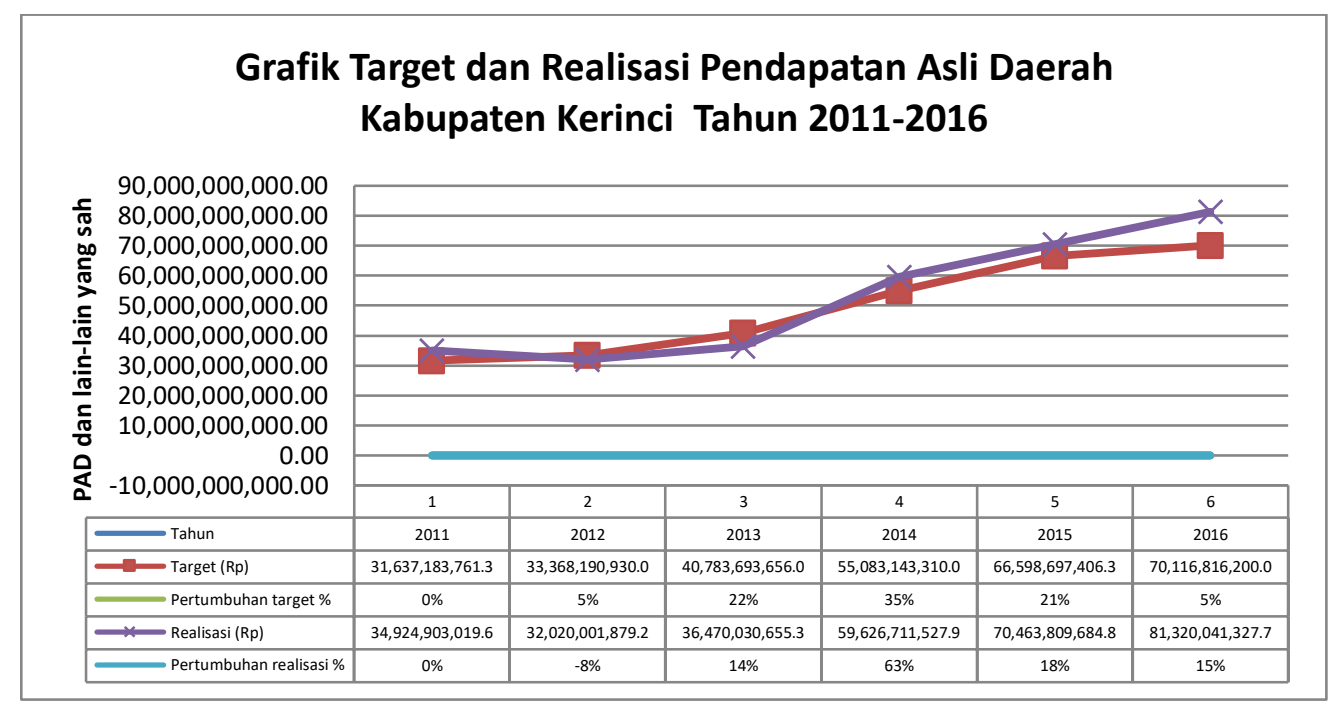

Gambar 1

Grafik Pertumbuhan Target dan Realisasi Pendapatan Asli Daerah di Kabupaten Kerinci Tahun 2011-2016

\section{Pertumbuhan Target dan Realisasi Dana Perimbangan di Kabupaten Kerinci}

Pada tabel 3 berikut ini dapat dilihat persentase pertumbuhan target dan realisasi Dana Perimbangan di Kabupaten Kerinci selama 6 (enam) tahun terakhir dari tahun 2011 sampai dengan 2016 dijelaskan bahwa secara nominal target penerimaan Dana Perimbangan dari tahun 2011 - 2016 secara total sebesar Rp. 3.767.521.,800.135,20 atau rata-rata pertahun sebesar Rp. 627.920.300.022,53. Begitu juga dengan persentase pertumbuhan target penerimaan Dana Perimbangan mengalami fluktuasi. Pada tahun 2012 persentase pertumbuhan target Dana Perimbangan sebesar 15,23\%, Tahun 2013 sebesar 16,14\%, sedangkan tahun 2014 mengalami penuruanan sehingga hanya tumbuh 5,64\%. Pada tahun 2015 target pertumbuhan penerimaan Dana Perimbangan mengalami penurunan $(2,67 \%)$ dan tahun 2016 pertumbuhan naik kembali menjadi 7,57\%. 


\section{Tabel 3}

Persentase Pertumbuhan Target dan Realisasi Dana Perimbangan Di Kabupaten Kerinci Tahun 2011 - 2016

\begin{tabular}{ccccc}
\hline \multirow{2}{*}{ Tahun } & Target (Rp) & $\begin{array}{c}\text { Target dan Realisasi Dana Perimbangan } \\
\text { Pertumbuhan }\end{array}$ & Realisasi $(\mathrm{Rp})$ & $\begin{array}{c}\text { Pertumbuhan } \\
(\%)\end{array}$ \\
\hline 2011 & $485.476 .282 .253,20$ & - & $498.122 .606 .258,83$ & - \\
2012 & $559.436 .816 .328,00$ & $15,23 \%$ & $588.567 .045 .360,00$ & $18,16 \%$ \\
2013 & $649.704 .772 .573,00$ & $16,14 \%$ & $647.505 .131 .112,00$ & $10,01 \%$ \\
2014 & $686.336 .931 .769,00$ & $5,64 \%$ & $673.545 .200 .956,00$ & $4,02 \%$ \\
2015 & $667.988 .061 .212,00$ & $-2,67 \%$ & $657.794 .536 .662,00$ & $-2,34 \%$ \\
2016 & $718.578 .936 .000,00$ & $7,57 \%$ & $716.530 .728 .762,00$ & $8,93 \%$ \\
Jumlah & $3.767 .521 ., 800.135,20$ & $41,91 \%$ & $3.782 .065 .249 .110,83$ & $38,78 \%$ \\
Rata-rata & $627.920 .300 .022,53$ & $8,38 \%$ & $630.344 .208 .185,14$ & $7,76 \%$ \\
\hline
\end{tabular}

Sumber : Data diolah

Sedangkan persentase pertumbuhan realisasi penerimaan Dana Perimbangan tahun 2011 sampai dengan 2016 mengalami fluktuasi. Pada tahun 2012 Penerimaan Dana Perimbangan mengalami pertumbuhan sebesar 18,16\% Pada tahun 2013 persentase pertumbuhannya 10,01\%. Pada tahun 2014 persentase pertumbuhan masih ada yaitu 4,02\%. Pada tahun 2015 pertumbuhan realisasi penerimaan Dana Perimbangan turun $-2,34 \%$ dan tahun 2016 tumbuh 8,93\%. Adapun Grafiknya dapat dilihat pada gambar grafik 2

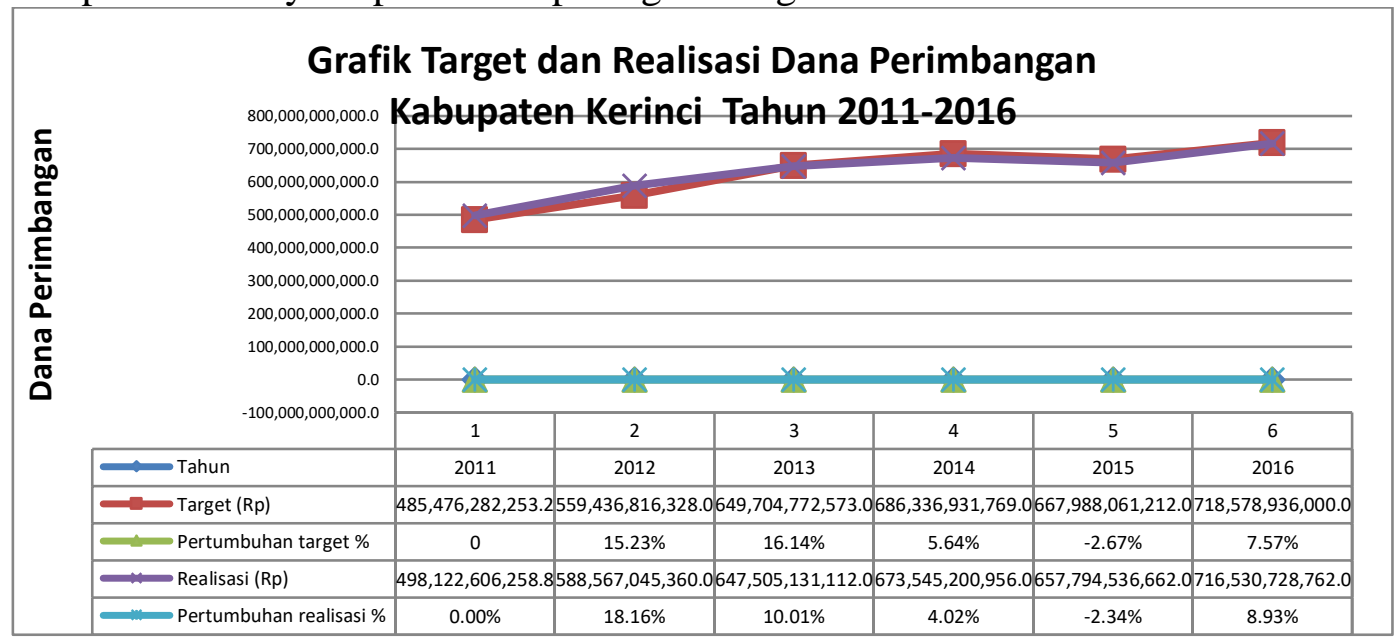

Gambar 2

Grafik Pertumbuhan Target dan Realisasi Dana Perimbangan di Kabupetan Kerinci Tahun 2011-2016

\section{Efektivitas Pendapatan Asli Daerah di Kabupaten Kerinci}

Berdasarkan pada data yang diperoleh dari Badan Pengelola Pajak dan Retribusi Daerah Kabupaten Kerinci, dapat dilihat dapat dilihat hasil perhitungan efektivitas Pendapatan Asli Daerah di Kabupaten Kerinci Tahun 2011 - 2016 secara rata-rata realisasi lebih besar dibandingkan dengan target dimana masuk kriteria sangat efektif dengan nilai rata-rata sebesar $105.79 \%$, data bisa dilihat pada tabel 4. 
Tabel 4

Efektivitas Pendapatan Asli Daerah

Di Kabupaten Kerinci Tahun 2011 - 2016

\begin{tabular}{|c|c|r|r|c|}
\hline Tahun & Target (Rp) & Realisasi (Rp) & Efektivitas & Keterangan \\
\hline 2011 & $31.637 .183 .761,36$ & $34.924 .903 .019,66$ & $110,39 \%$ & Sangat Efektif \\
\hline 2012 & $33.368 .190 .930,00$ & $32.020 .001 .879,23$ & $95,96 \%$ & Efektif \\
\hline 2013 & $40.783 .693 .656,00$ & $36.470 .030 .655,34$ & $89,42 \%$ & Cukup Efektif \\
\hline 2014 & $55.083 .143 .310,00$ & $59.626 .711 .527,91$ & $108,25 \%$ & Sangat Efektif \\
\hline 2015 & $66.598 .697 .406,32$ & $70.463 .809 .684,80$ & $105,80 \%$ & Sangat Efektif \\
\hline 2016 & $70.116 .816 .200,00$ & $81.320 .041 .327,77$ & $115,98 \%$ & Sangat Efektif \\
\hline Jumlah & $297.587 .725 .263,68$ & $314.825 .498 .094,71$ & $105,79 \%$ & Sangat Efektif \\
\hline Rata-Rata & $49.597 .954 .210,61$ & $52.470 .916 .349,12$ & $105,79 \%$ & Sangat Efektif \\
\hline
\end{tabular}

Sumber: Data diolah

Dari tabel 4 di atas dapat dijelaskan bahwa pada tahun 2011 kriteria efektivitas Pendapatan Asli Daerah adalah sangat efektif dilihat dari percentasi efektivitas sebesar 110,39\% , Untuk tahun 2012 realisasi menurun hanya tercapai 95,96\% tercapai kriterianya Efektif saja. Tahun 2013 mengalami penuruanan dari taeget yang ada yaitu masuk kategori Cukup Efektif dengan percentasi efektivitas hanya $89,42 \%$. hal tersebut dikarenakan kondisi perekonomian masyarakat sedang menurun diantaranya banyak hasil tani gagal panen, pasar juga lesu, hal tersebut menurunkan PAD, selain itu juga masa transisi kepala daerah Kabupaten Kerinci. Sedangkan tahun 2014 sampai dengan tahun 2016 kriterinya sangat efektif dimana rata-rata percentasi efektivitasnya diatas $100 \%$.. Adapun Grafik efektivitas Pendapatan Asli Daerah dapat dilihat sebagai berikut:

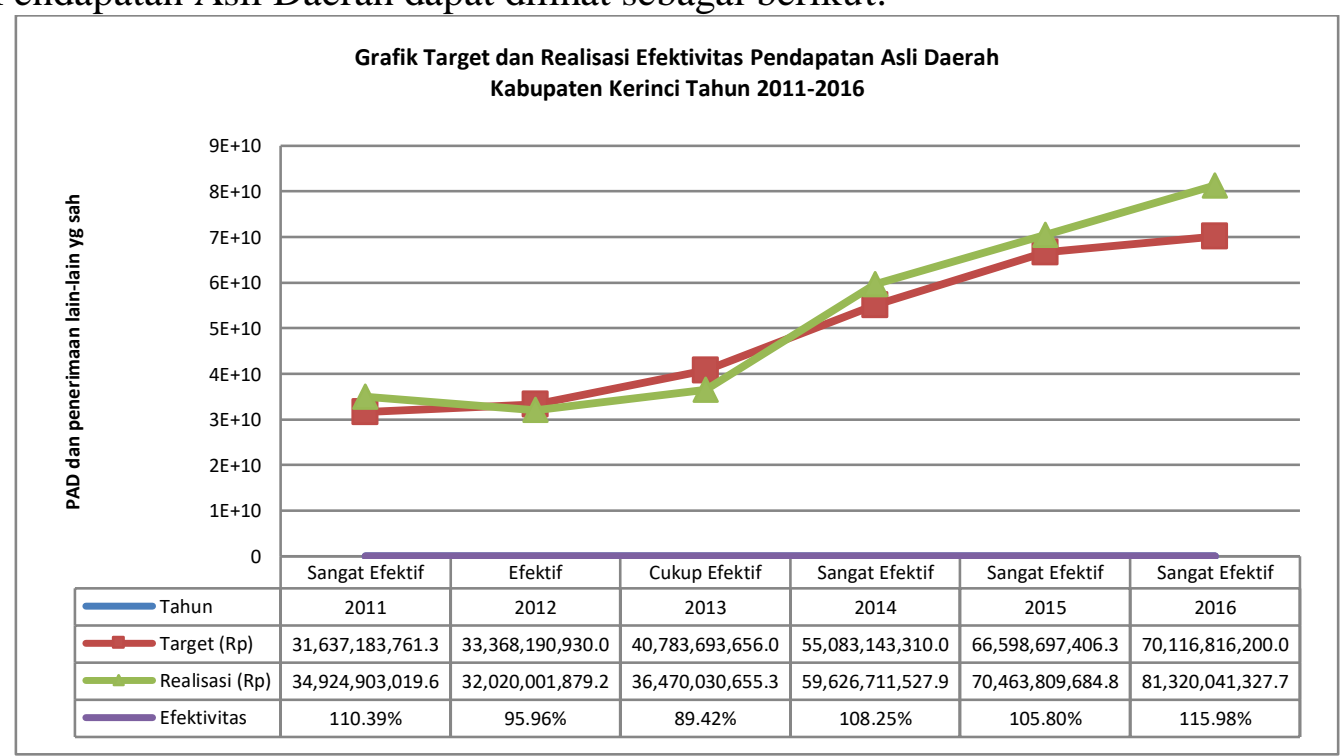

Gambar 3

Grafik efektivitas Pendapatan Asli Daerah di Kabupaten Kerinci Tahun 2011-2016

\section{Efektivitas Dana Perimbangan Kabupaten Kerinci}

Berdasarkan Tabel kita bisa melihat hasil efektivitas Dana Perimbangan di Kabupaten Kerinci dengan data sebagai berikut: 


\section{Tabel 5}

Efektivitas Dana Perimbangan

Di Kabupaten Kerinci Tahun 2011 - 2016

\begin{tabular}{|c|c|c|c|c|}
\hline Tahun & Target $(\mathrm{Rp})$ & Realisasi $(\mathrm{Rp})$ & Efektivitas & Keterangan \\
\hline 2011 & $485.476 .282 .253,20$ & $498.122 .606 .258,83$ & $102,60 \%$ & Sangat Efektif \\
\hline 2012 & $559.436 .816 .328,00$ & $588.567 .045 .360,00$ & $105,21 \%$ & Sangat Efektif \\
\hline 2013 & $649.704 .772 .573,00$ & $647.505 .131 .112,00$ & $99,66 \%$ & Efektif \\
\hline 2014 & $686.336 .931 .769,00$ & $673.545 .200 .956,00$ & $98,14 \%$ & Efektif \\
\hline 2015 & $667.988 .061 .212,00$ & $657.794 .536 .662,00$ & $98,47 \%$ & Efektif \\
\hline 2016 & $718.578 .936 .000,00$ & $716.530 .728 .762,00$ & $99,71 \%$ & Efektif \\
\hline Jumlah & $3.767 .521 .800 .135,20$ & $3.782 .065 .249 .110,83$ & $100,39 \%$ & Sangat Efektif \\
\hline Rata-rata & $627.920 .300 .022,53$ & $630.344 .208 .185,14$ & $100,39 \%$ & Sangat Efektif \\
\hline
\end{tabular}

Sumber: Data diolah

Berdasarkan hasil perhitungan tingkat efektivitas Dana Perimbangan di Kabupaten Kerinci dari tahun 2011 sampai dengan 2016 secara rata-rata realisasinya melebihi dari target yang ditetapkan. Artinya bahwa secara kriteria efektivitas termasuk kategori sangat efektif dengan rata-rata percentasi efektivitas sebesar $100,39 \%$.

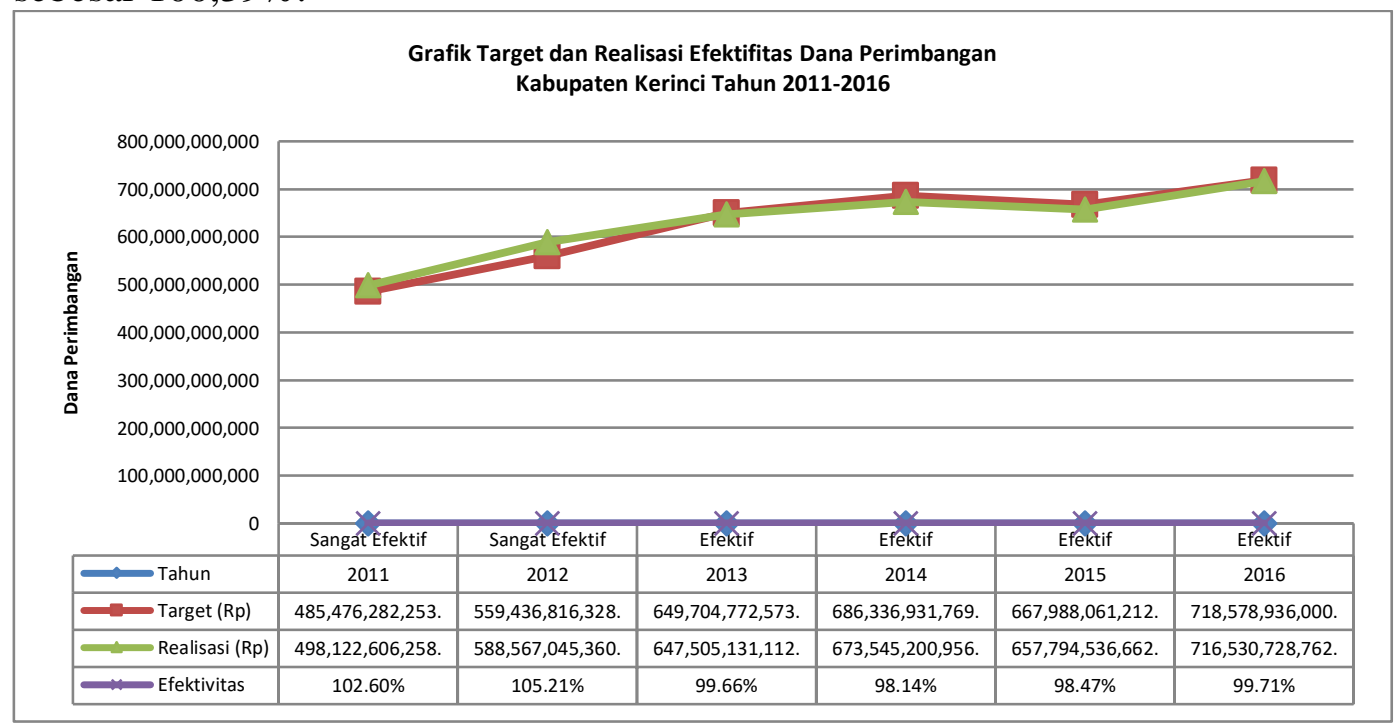

\section{Gambar 4 \\ Grafik Efektivitas Dana Perimbangan di Kabupaten Kerinci}

Pada tahun 2011 kriteria efektivitas Dana Perimbangan sangat efektif dengan percentasi efektivitas sebesar 103,06\%, dan Tahun 2012 juga sangat efektif dengan percentasi efektifitas 105,19\%.untuk tahun 2013 mengalami sedikit penurunan dari target yang ada. Dimana hanya masuk kriteria efektif dengan percentasi efektivitas sebesar 99,75\%. Sedangnkan tahun 2014 mengalami kenaikan kembali yaitu sangat efektif dengan percentasi efektivitas $100,06 \%$. Untuk Tahun 2015 dan 2016 hanya masuk kriteria efektif dimana percentasi tahun 2015 sebesar 98,65\% dan tahun 2016 sebesar 97,39\%.. Secara keseluruhan penerimaan Dana Perimbangan dari tahun ke tahun mengalami kenaikan, hal tersebut bisa dilihat dari nilai realisasi penerimaan Dana Perimbangan, Dengan adanya kenaikan Dana Perimbangan harapannya dapat meningkatkan pembangunan, baik itu infrastruktur, pendidikan, peningkatan dibeberapa sector lainnya sehingga meningkatkan pendapatan dan kesejahteraan masyarakat sehingga program pembangunan daerah bisa tercapai. 


\section{SIMPULAN}

Berdasarkan hasil pembahasan, maka dapat diambil beberapa kesimpulan sebagai berikut:

1. Pertumbuhan Penerimaan Pendapatan Asli Daerah di Kabupaten Kerinci, dijelaskan bahwa secara nominal target penerimaan pendapatan asli daerah yang sah dari tahun 2011 - 2016 selalu mengalami peningkatan. Sedangkan persentase pertumbuhannya mengalami fluktuasi. Rata- Rata Target nominal selama 6 tahun tahun 2011-2016 sebesar Rp. 49.597.954.211, dimana rata-rata target percentase tahun 2011-2016 sebesar $17.79 \%$.

2. Pertumbuhan Target dan Realisasi Dana Perimbangan di Kabupaten Kerinci, dapat dilihat persentase pertumbuhan target dan realisasi Dana Perimbangan di Kabupaten Kerinci selama 6 (enam) tahun terakhir dari tahun 2011 sampai dengan 2016 dijelaskan bahwa secara nominal target penerimaan Dana Perimbangan dari tahun 2011 - 2016 secara total sebesar Rp. 3.767.521.,800.135,20 atau rata-rata pertahun sebesar Rp. 627.920.300.022,53. Begitu juga dengan persentase pertumbuhan target penerimaan Dana Perimbangan mengalami fluktuasi yaitu rata-rata 20,53\%.

3. Efektivitas Pendapatan Asli Daerah di Kabupaten Kerinci Tahun 2011 - 2016, secara rata-rata realisasi lebih besar dibandingkan dengan target dimana masuk kriteria sangat efektif dengan nilai rata-rata sebesar $105.79 \%$

4. Efektivitas Dana Perimbangan di Kabupaten Kerinci Tahun 2011-2016, secara rata-rata realisasinya melebihi dari target yang ditetapkan. Artinya bahwa secara kriteria efektivitas termasuk kategori sangat efektif dengan rata-rata percentasi efektivitas sebesar 100,39\%.

\section{Saran}

1. Diharapkan kepada Pemerintah Kabupaten Kerinci dalam menetapkan target Pendapatan Asli Daerah dapat dimanfaatkan dengan baik untuk pembangunan daerah Kabupaten Kerinci sehingga pembangunan daerah disegala bidang dapat meningkat dengan baik dengan cara perbaikan managemen operasional dibeberapa sector yang dapat meningkatkan Pendapatan Asli daerah seperti di Sektor Pariwisata, sector Pertanian dengan pemberian pupuk unggul, pemberian penyuluhan kepada petani untuk meningkatkan hasil pertanian dan Peningkatann kinerja dan usaha BUMD seperti PDAM sehingga kegiatan yang ada lebih efektif dan Penadapatan Asli Daerah Meningkat

2. Sedangkan untuk Dana Perimbangan dimana Secara finansial nilainya cukup besar tetapi pembangunan yang ada belum begitu optimal terbukti masih banyak Jalan-jalan yang rusak, sekolah yang belum bagus dan optimaliasasi penyerapan dana perimbangan masih belum merata. Oleh karena itu perlu adanya realisasi Dana perimbangn yang jelas sesuai dengan kebutuhan daerah seperti perbaikan infrastruktur jalan, sekolah dan sarana tempat umum seperti pasar sehingga perekonomian masyarakatpun meningkat.

\section{DAFTAR PUSTAKA}

Adisasmita. H.R. 2005. Dasar-dasar Ekonomi Wilayah. Jakarta: Graha Ilmu.

Ahmad, Yani. 2002. Hubungan Keuangan Antara Pemerintah Pusat dan Daerah. Jakarta: Grafindo

Alfarisi, Salman.2015. Pengaruh Pajak Daerah, Retribusi Daerah, Dan Dana Perimbangan Terhadap Kinerja Keuangan Pemerintah Daerah. Fakultas Ekonomi Universitas Negeri Padang. 
Bastian, Indra. 2006. Akuntansi Sektor Publik: Suatu Pengantar. Jakarta: Erlangga.

Djaenuri, Aries 2012. Hubungan Keuangan Pusat-Daerah. Penerbit Ghalia Indonesia.

DPPKAD dan Laporan Kinerja Kabupaten Kerinci Tahun 2016

Fahmi, Irham. 2011. Analisis Laporan Keuangan. Lampulo: ALFABETA

Fakih, Mansour. 2001. Runtuhnya Teori Pembangunan dan Globalisasi. Yogyakarta: Insistpres bekerjasama dengan Pustaka Pelajar.

Halim Abdul. 2004. Akuntansi Keuangan Daerah. Salemba Empat. Jakarta.

Halim.Abdul.2002.Akuntansi Keuangan Daerah.Penerbit Salemba Empat.Jakarta

Indrawan, M. Yusuf. 2013. Faktor-Faktor yang Memengaruhi Kinerja Keuangan. Yogyakarta: BPFE

Irawan dan Suparmoko. 2002. Ekonomi Pembangunan. Yogyakarta: BPFE.

Jhingan, 2000.Ekonomi Pembangunan dan Perencanaan.Rajawali Press.Jakarta.

Julitawati, dkk. 2012. Pengaruh Pendapatan Asli Daerah (PAD) dan Dana Perimbangan Terhadap Kinerja Keuangan Pemerintah Kabupaten/Kota Di Provinsi Aceh. Jurnal Akuntansi Pascasarjana Universitas Syiah Kuala. Aceh. Vol.1, No. 1: 1-15.

Jumingan. 2006. Analisis Laporan Keuangan, Cetakan Pertama, PT Bumi Aksara, Jakarta.

Mardiasmo. 2004 Otonomi dan Manajemen keuangan daerah. Penerbit Andi: Yogyakarta.

Mardiasmo. 2013. Otonomi dan Manajemen Keuangan Daerah. Yogyakarta: Andi Offset.

Mokodompit, Sandy Paramitha. 2014. Analisis Pengukuran Kinerja Keuanganpada Pemerintah Kabupaten/Kota Se-Provinsi Sulawesi Selatan.Makassar:Jurusan Akuntansi Fakultas Ekonomi dan Bisnis Universitas Hasanuddin.

Peraturan Menteri Dalam Negeri Nomor 13 tahun 2006 tentang Pedoman Pengelolaan Keeeuangan Daerah

Peraturan Pemerintah Nomor 58 Tahun 2005 tentang Pengelolaan Keuangan Daerah

Standar Akuntansi Pemerintah

Subowo dan Endar Rosita Wati.2010. "Hubungan Antara PAD Dan Dana Perimbangan

Sukirno, Sadono. 2000. Ekonomi Pembangunan. Jakarta : LPEF-UI Bima Grafika.

Suryana, 2002. Ekonomi Pembangunan: Problematika dan Pendekatan. Jakarta: Salemba Empat.

Trijono, Lambang. 2007. Pembangunan Sebagai Perdamaian. Jakarta: Yayasan Obor Indonesia.

Undang - Undang No. 17 Tahun 2003 Tentang Keuangan Negara

Undang- Undang Nomor 44 Tahun 1999 Kemudian digantikan oleh Undangundang Republik Indinesia Nomor 12 Tahun 2008 Tentang Pemerintah daerah

Undang-Undang No. 28 tahun 2009 Tentang Pajak Daerah dan Retribusi Daerah. Undang-undang No. 22 Tahun 1999 Tentang Pemerintah Daerah

Undang-Undang No. 32 Tahun 2004 tentang Pemerintah Daerah serta UU No. 33 Tahun 2004 tentang Perimbangan Keuangan antara Pemerintah Pusat dan Daerah 
Undang-undang No.33 Tahun 2004 tentang Perimbangan Keuangan antara Pemerintah Pusat dan Pemerintah Daerah.

Undang-Undang Nomor 01 Tahun 2004 tentang Pembndaharaan Negara

Undang-Undang Nomor 12 Tahun 2008 Tentang Pemerintah Daerah

Wahyuningsih, Yoshinta Endah. 2016. Pengaruh Pendapatan Asli Daerah (PAD) dan Dana Perimbangan Terhadap Kinerja Keuangan Pemerintah Kabupaten/Kota di Provinsi Jawa Tengah. Skripsi. Universitas Muhammadiyah Surakarta.

Wenny,Cherry Dhia. 2012. Analisis Pengaruh Pendapatan Asli Daerah (PAD) Terhadap Kinerja Keuangan pada Pemerintah Kabupaten dan Kota di Provinsi Sumatera Selatan. Forum Bisnis Dan Kewirausahaan Jurnal Ilmiah STIE MDP. 2 (1): 39-51.

Yuwono, Soni. Dkk. 2005. Penganggaran sektor publik.Bayu Media Publissing. Surabaya. 